\title{
An analysis of azerbaijani turkish translations of civil and criminal ayas of the holy qur'an: a forensic linguistic perspective
}

\begin{abstract}
This papers aims to provide an analysis of the Azerbaijani Turkish translations of civil and criminal Ayas of the Holy Qur'an using a forensic linguistic perspective. The corpus of the current study is the relevant Ayas and their Azerbaijani Turkish translations provided by Kavyanpoor and Esmaeilzadeh. The analysis of the data shows that interpretation of discursive structures in civil and criminal Ayas of the Holy Qur'an is critical in saving or losing forensic discourse of the Holy Qur'an. This study also confirms that these discursive structures have forensic senses that serve a very important role in translating the Holy Qur'an.
\end{abstract}

Keywords: civil and criminal Ayas, forensic linguistic, Azerbaijani Turkish, translation
Volume 6 Issue 3 - 2018

\author{
Mostafa Shahiditabar,' Karim Torabi, ${ }^{2}$ \\ Peyaman Hassani, ${ }^{3}$ Mohammad Amin \\ Mozaheb' \\ 'Department of Foreign Languages, Imam Sadiq University, Iran \\ ${ }^{2}$ Zanjan PNU University, Iran \\ ${ }^{3}$ Imam Sadiq University, Iran
}

\begin{abstract}
Correspondence: Mohammad Amin Mozaheb, Language Center, Head of the Department of Foreign Languages, Imam Sadiq University, Tehran, No-69l-Next to Kashiha Bus Station, Namjoo Street, Enghelab Avenue, Iran, Tel +989I22129216, Email mozaheb.ma@gmail.com
\end{abstract}

Received: April 15, 2018 | Published: May 07, 2018

\section{Introduction}

Legal or forensic linguistic is a branch of applied linguistics that is the application of knowledge and linguistic methods in the context of the law. The life of this science is less than three decades and is a result of a combination of linguistics and law, using linguistic tools which can help us analyze texts in a professional manner. It can also help police and jurisdictions discover the truth in legal cases and help us in prove the circumstances of a crime. This is the reason forensic linguistics is important in many countries. Initially, some people, especially judges, were not satisfied with forensic linguistics because they thought it would be a threat to them and their jobs. After a while, they understood that this method can help them to discover the reality easier than before by means of forensic linguistics. There are some areas of application for linguists that work on forensic contexts such as the following: understanding language of written law and understanding language use in forensic and judicial processes etc. The discipline of forensic linguistics is not homogenous; it involves a range of experts and researchers in different areas of the field.

\section{Importance of study}

The purpose of the current study is to bridge the gap between forensic linguistic and CDA. In other words, it strives to study the Azerbaijani Turkish translations of the Holy Qur'an to see whether the translations have been successful in transferring the complete relevant meanings. Since studying and applying forensic linguistics in Iran is a new domain for linguists and law experts, this study is one of the first attempts to consider translations of the Holy Qur'an using a forensic linguistic perspective.

\section{Review of literature}

A brief review of literature shows that many scholars of forensic linguistics and CDA experts have frequently tried to analyze relevant texts. Arjmandi et al., ${ }^{1}$ have conducted a comparative study of Farsi and English translations of the Holy Qur'an using a forensic linguistic perspective. This study reports that interpretation of discursive structures in civil and criminal Ayas of the Holy Qur'an is curtail in saving and losing forensic discourse of the Holy Qur'an. Ogunsiji et al., ${ }^{2}$ confirm that pragmatics is indispensable in forensic linguistics since people do not always say what they mean. This study proves that people's words do not always correspond with their will. As far as Ogunsiji et al.,, ${ }^{2}$ are concerned, people's expressions are open to interpretation by their listeners, thereby resulting to 'mistaken understanding, miscommunication and eventually conflict'. According to this study, judges make use of pragmatics all the time in their judgments on the one hand and lawyers and prosecutors make use of language to do things with words on the other hand. Leonard ${ }^{3}$ studies the scientific principles of language analyses to issues of the law using a forensic linguistic perspective. It gives some samples from Roger Shuy and also a case from linguists Benji Wald. According to this paper, the main use of forensic linguistic is to understand law.

\section{Methodology}

Fairclough ${ }^{4}$ believes that language application is surrounded with social processes. It has some relationship that makes the context like forensic context. The framework used in this study is based on Fairclough $^{4}$ and Fairclough. ${ }^{5}$

\section{Corpus}

The materials used in this study are the transcripts of Obama's speeches from 2011 to 2015 .

\section{Results}

The results are seen in the following: 


\section{Word choice and the importance of equivalents}

Legal discourse supporting legal personality: absorbing and

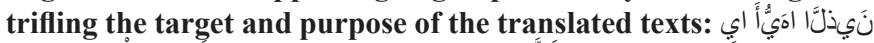

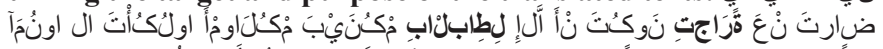

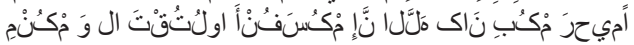

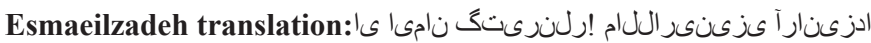

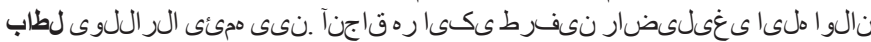

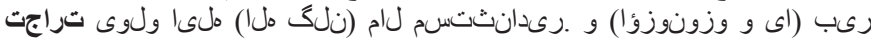
.رى .

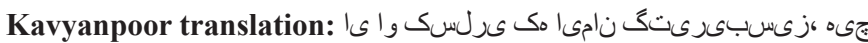

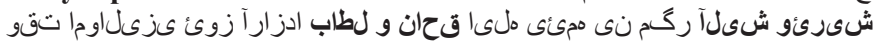

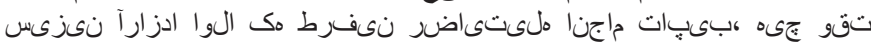

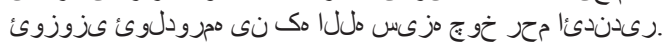

In this Aya, two words are going to be explained; (لِطِابنَاب) and (مثَّاجت. Esmaeilzadeh has chosen the same Arabic word in translation while Kavyanpoor has chosen the same word and a helping word to emphasize the meaning in the target text. It means that the translator has picked two different adjectives to imply one concept. The same strategy is used in the second word, (ثرَّراجت) in a different way. Esmaeilzadeh has chosen the same Arabic word in translation, while Kavyanpoor has picked a two-part Turkish equivalent.

Legal discourse supporting legal personality: devaluing the target

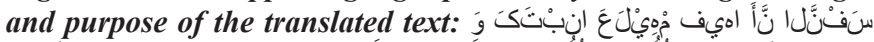

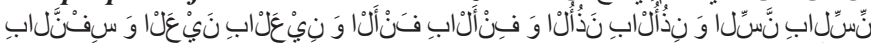

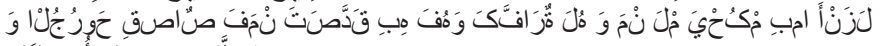

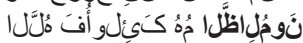

:ىى قى قدزاى (ادتاروت) ادنوا ار النوا زىب:Esmaeilzadeh translation

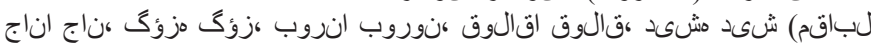

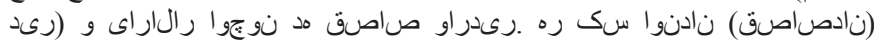

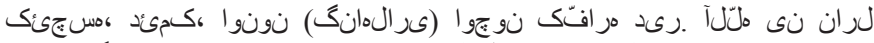

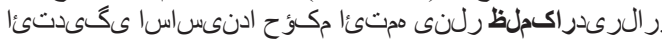

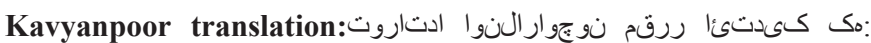

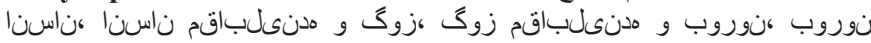

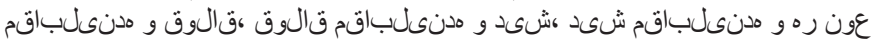

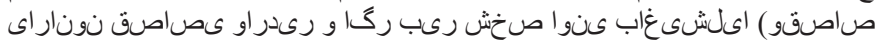

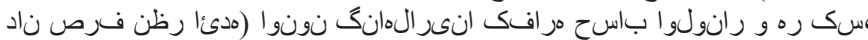

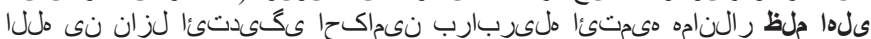
رلند.

This Aya is about Qisas. Both translators have devaluated Qisis in their translations. Esmaeilzadeh has chosen (راكملظ) while Kavyanpoor has chosen (علىlo ملظ). The mentioned words cannot state the concept of Qisas completely.

Legal discourse supporting spiritual personality of people:

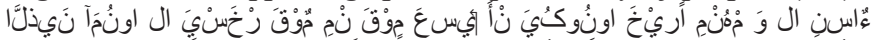

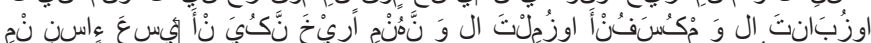

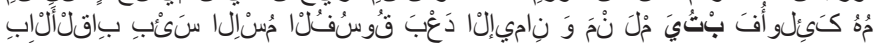
نَومُلِاظِلَّاُ

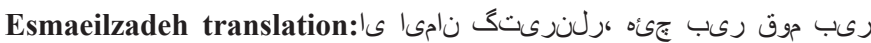

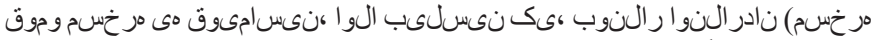

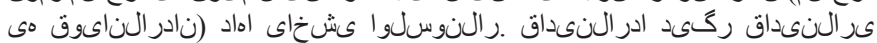

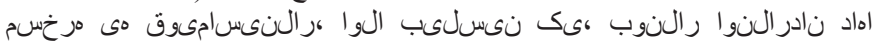

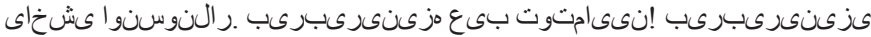

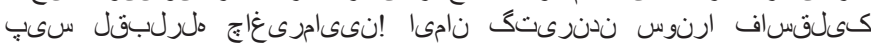

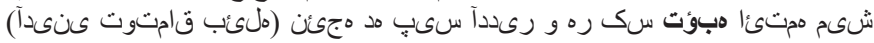

.ر الرى اكدر اكلظ (ر النوا ،ىك نىسلىب) ،مس .

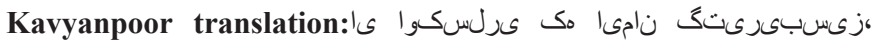

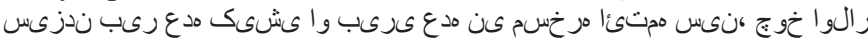

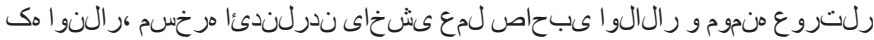

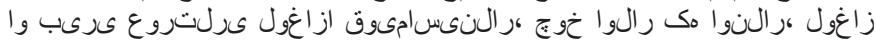

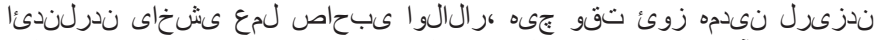

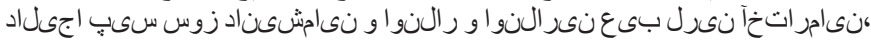

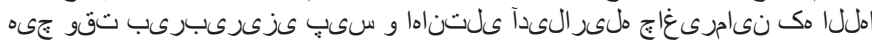

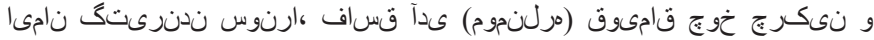

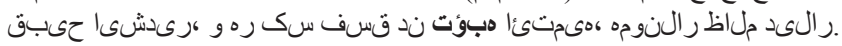

This Aya confirms the inherent dignity and equal inalienable right of all members of a human family and does not let anyone lose his face. Both translators have chosen (هبؤت) to transfer the meaning in Azerbaijani Turkish.

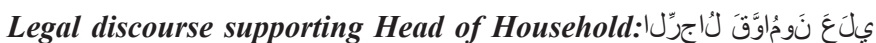

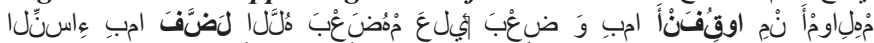

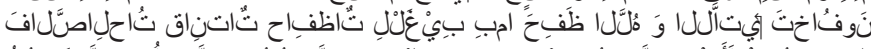

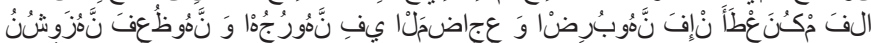

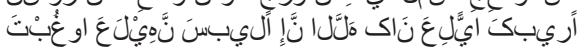

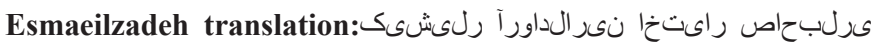

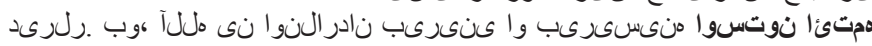

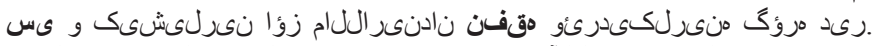

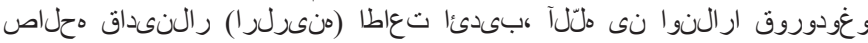

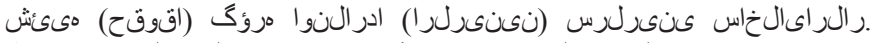

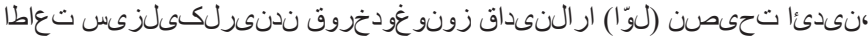

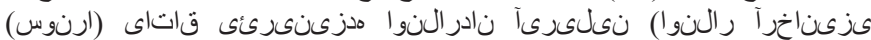

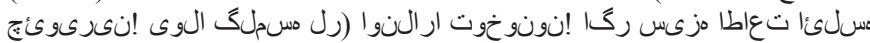

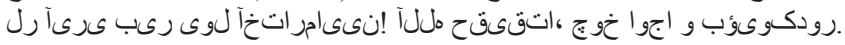

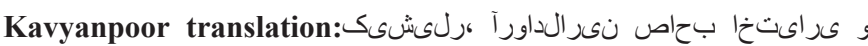

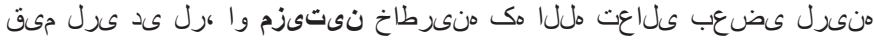

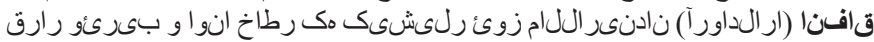

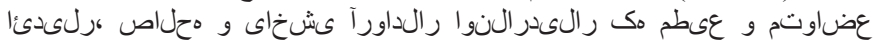

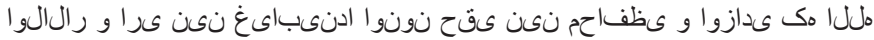

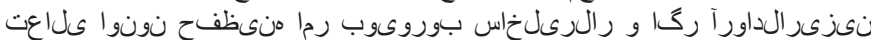

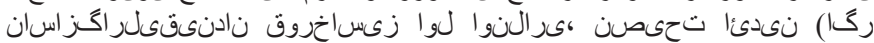

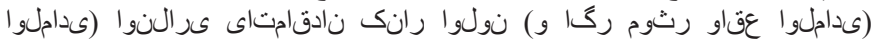

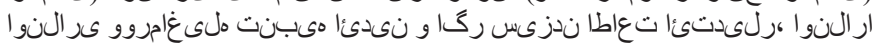

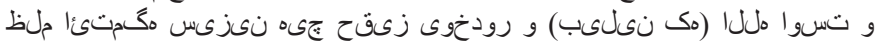

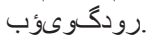

This Aya confirms that man is the responsible member of the family in Islamic viewpoint. It supports head of household and both

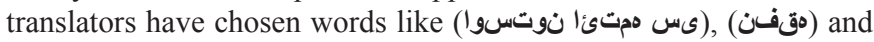
(نقىن) to convey the discussed issue.

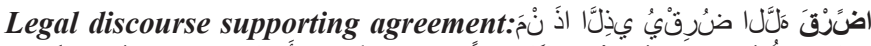

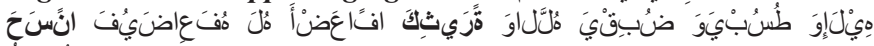

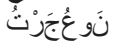

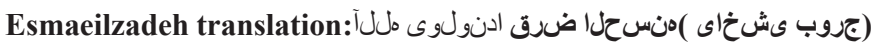

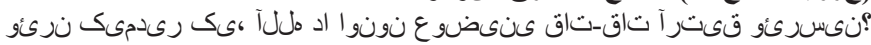

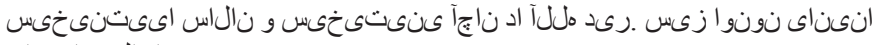

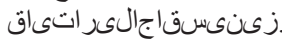

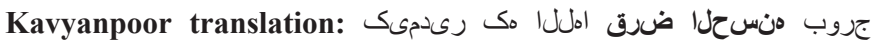

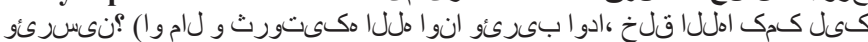

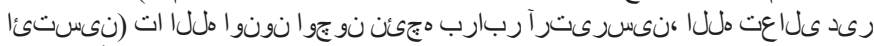

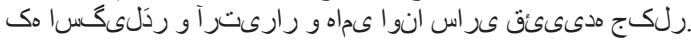




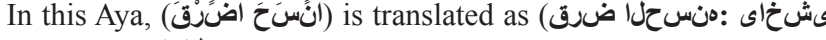

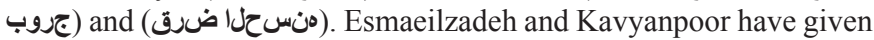
the same Arabic words in translation on the one hand. Esmaeilzadeh provides a literal translation for the same word in Azerbaijani Turkish on the other hand.

Legal discourse supporting legality of crime and punishment:نَ

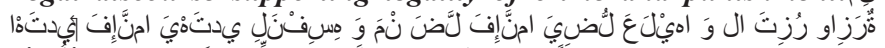

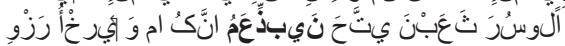

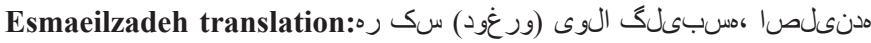

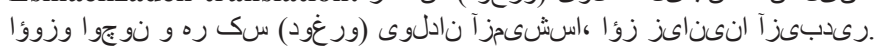

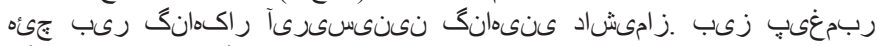

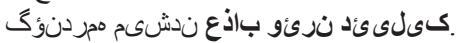

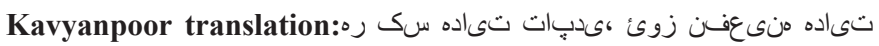

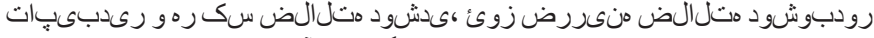

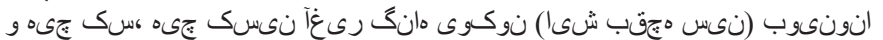

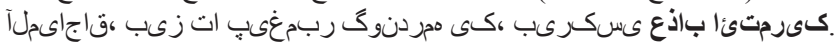

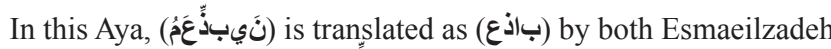

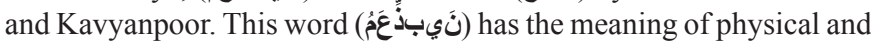
mental chastisement. Both translators are successful in transferring the proposed concept. It means the ideological loan of forensic discursive structure of this word has not changed. To sum up, the translators have succeeded in saving the ideological loan of forensic discursive structure of this word.

\section{Representation of passive versus active voices}

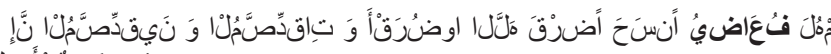

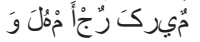

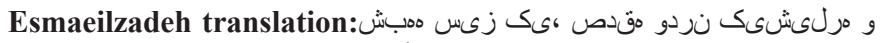

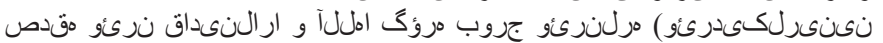

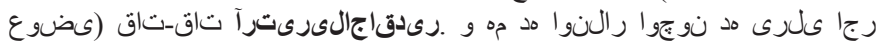

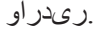

ملال هك رلتروع و او رلىشى ولى وا هدتقىقح:Kavyanpoor translation

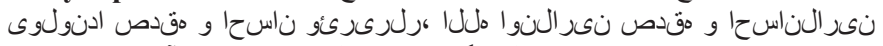

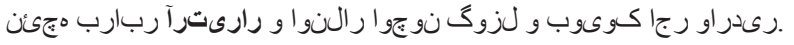

In this Aya, (نُعَاضين) is a passive voice verb. It is translated as by Esmaeilzadeh and (رىدقاجالهرىثرآ) by Kavyanpoor. Esmaeilzadeh has chosen the passive voice while Kavyanpoor has chosen active voice. It can be argued that representation of passive in the relevant Aya is passive in one translation and active in another translation.

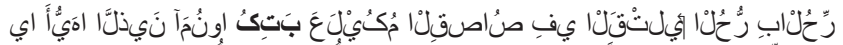

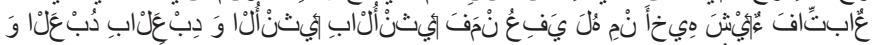

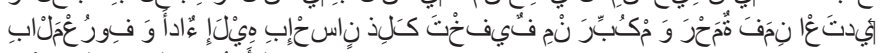

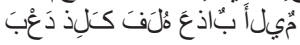

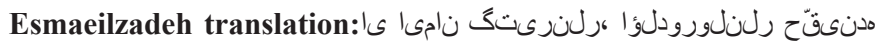

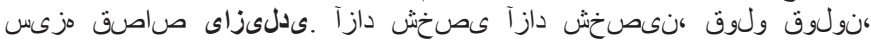

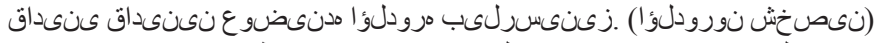

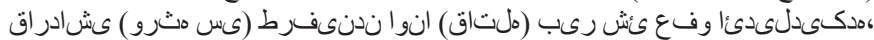

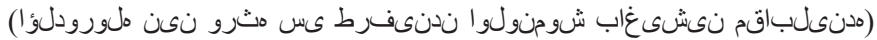

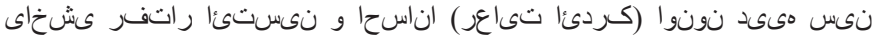

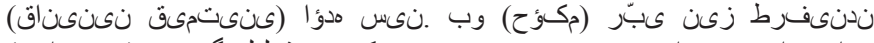

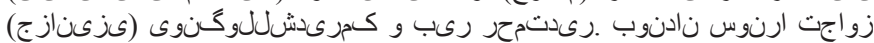

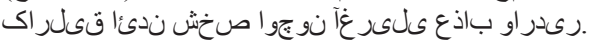

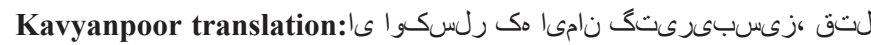

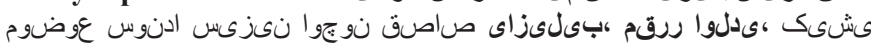

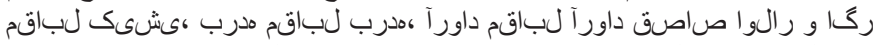

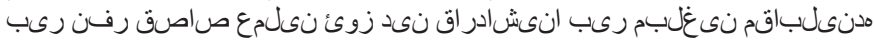

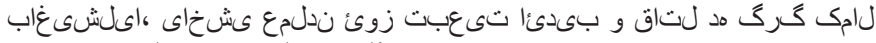

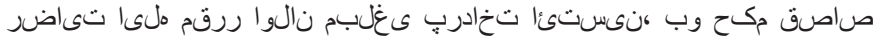

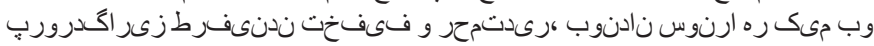

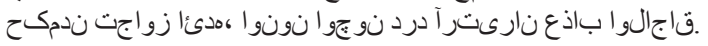

This Aya is about criminal responsibility. In this Aya (بَتتكُ) is in passive voice. Both translators have chosen passive voice to transfer the relevant concept.

\section{Conclusion}

In analyzing the Azerbaijani Turkish translations of civil and criminal Ayas of the Holy Qur'an using a forensic linguistic perspective, it can be argued that the Ayas of the Holy Qur'an are studied in different domains as supporting legal personality as absorbing and trifling the target and purpose of the translated texts and devaluing the target and purpose of the translated texts, supporting spiritual personality of people, supporting Head of Household, loan agreement, legality of crime and punishment and representation of passive versus active voices. Then, discursive structures in civil and criminal Ayas of the Holy Qur'an are extracted. The results show that interpretation of discursive structures in civil and criminal Ayas of the Holy Qur'an is crucial in saving or losing forensic discourse of the Holy Qur'an that confirms Arjmandi \& Azimdokht. ${ }^{1}$ This study proves that these discursive structures have forensic senses that have a very important role in translation.

\section{Acknowledgement}

None.

\section{Conflict of interest}

Authors declare that there is no conflict of interest.

\section{References}

1. Arjmandi M, Azimdokht Z. An analysis of forensic discursive structures in civil and criminal Ayas of the Holy Qur'an: A forensic and critical perspective (In Farsi). Proceedings of the First National Forensic Linguistics: Forensic Discourse Analysis. 2014;35-54.

2. Ogunsiji Y, Farinde RO. Pragmatics in forensic linguistic development for national re-orientation and transformation in Nigeria. British Journal of Arts and Social Sciences. 2012;7(II),113-121.

3. Leonard RA. Forensic linguistics: Applying the scientific principles of language analysis to issues of the Law. International Journal of the Humanities. 2005;3(2):112-122.

4. Fairclough N. Critical discourse analysis. London: Longman; 1995:1-27.

5. Fairclough N. Language and power. London: Longman; 2001: 1 p. 